\title{
Assessment and repair of critical misconceptions in engineering heat transfer and thermodynamics
}

\section{Dr. Michael J. Prince, Bucknell University}

Dr. Margot A Vigeant, Bucknell University

Dr. Margot Vigeant is an associate professor of chemical engineering and associate dean of engineering. She is interested in chemical engineering pedagogy, first-year programs, and international education.

\section{Dr. Katharyn E. K. Nottis, Bucknell University}

Dr. Nottis is an educational psychologist and professor of education at Bucknell University. Her research has focused on meaningful learning in science and engineering education, approached from the perspective of Human Constructivism. She has authored several publications and given numerous presentations on the generation of analogies, misconceptions, and facilitating learning in science and engineering education. She has been involved in collaborative research projects focused on conceptual learning in chemistry, chemical engineering, seismology, and astronomy. 
Assessment and Repair of Critical Misconceptions in Engineering Heat Transfer and Thermodynamics

\begin{abstract}
This final report from our NSF funded (DUE 0717536) study examines the use of inquiry-based teaching to promote misconception repair in four critical areas in heat transfer (rate of heat transfer vs. amount of energy transferred, confusion between temperature and energy, confusion between how something "feels" and its temperature, and confusion about radiation) and five critical areas in thermodynamics (Entropy, Equilibrium and Steady State, and Internal Energy and Enthalpy). Significant work demonstrates that students often enter the classroom with tightly held misconceptions about the physical world that are not effectively addressed through traditional lecture-style teaching. This work has two primary parts: the development and testing of a concept inventories to reliably assess students conceptual understanding in these areas and the development and assessment of inquiry-based activities designed to repair students' misconceptions.
\end{abstract}

For the instrument, reliability data was collected through both pre- and postcourse assessments at over 15 institutions nationwide. Results indicated that both the Heat and Energy Concept Inventory (HECI) and the Concept Inventory for Engineering Thermodynamics (CIET) instruments have sufficient reliability during post- testing for use as a research instruments. Results also indicate that students enter their courses with significant misconceptions in the relevant concept areas, tending to score about 50\% on pre-tests. While instruction does improve conceptual understanding significantly relative to the pre- course scores, average overall scores are still in the $60 \%$, indicating that further improvement is desirable.

One approach to the repair of misconceptions is through inquiry-based activities. In these activities, the instructor creates a laboratory or simulation situation where students may directly observe their misconceptions fail to explain the results while the correct concepts succeed. A set of two activities along with worksheets and explanatory materials was developed for each misconception area. These were tested at over 15 institutions. Use of these activities improves students' post- course scores on the concept inventories by about an additional 10 percentage points on average, a significant improvement over both the pre-test and the non-intervention case.

\title{
Introduction and Background
}

Students' conceptual understanding forms the basis for their transfer of learning from one context, such as classrooms, to another, such as their jobs [1]. Cultivating conceptual understanding is challenged by the preconceptions students hold based on their prior experiences. When faculty fail to engage and 
challenge these misconceptions, students often revert to their prior state after a class is completed.

Several approaches have shown promise in misconception repair. Our work is inspired by the Workshop Physics approach of Laws et al [2]. In this approach, students participate in inquiry-based activities that present direct challenges to students' most common misconceptions. Students are presented with physical situations or simulations in which the most-common misconceptions will lead them to make a false prediction of the outcome. For example, predicting that the temperature of a ceramic floor tile is lower than the temperature of a piece of wood. Students then actively engage in experimenting with the situation, taking the opportunity to convince themselves that reality is not as they had predicted. Students then reflect on their experience in order to cement their learning. The key aspects of Laws et al's approach are summarized in Table 1.

TABLE 1:Elements of Inquiry-Based Activity Modules [2]
(a) Use peer instruction and collaborative work
(b) Use activity-based guided-inquiry curricular materials
(c) Use a learning cycle beginning with predictions
(d) Emphasize conceptual understanding
(e) Let the physical world be the authority
(f) Evaluate student understanding
(g) Make appropriate use of technology
(h) Begin with the specific and move to the general

In this work, we identified four concept areas in heat transfer and five in thermodynamics that had potential to benefit from the creation of misconception repair activities. These concept areas are briefly described in Table 2.

TABLE 2: Concept Areas

\begin{tabular}{|l|l|l|}
\hline Area & Short Concept Name & Misconception \\
\hline Heat Transfer & Temperature vs. Energy & $\begin{array}{l}\text { Temperature is a direct indicator of the energy content of a } \\
\text { system. }\end{array}$ \\
\cline { 2 - 3 } & Temperature vs. "Feeling" & $\begin{array}{l}\text { How an object feels to the touch indicates its temperature } \\
\text { exclusively. }\end{array}$ \\
\cline { 2 - 3 } & Rate vs. Amount & $\begin{array}{l}\text { Factors which impact how quickly energy is transferred likewise } \\
\text { impact how much energy is transferred. }\end{array}$ \\
\cline { 2 - 3 } & Thermal Radiation & Color is the most important factor in radiative heat transfer. \\
\hline Thermodynamics & Entropy & Any system can be made 99.999999\% efficient \\
\cline { 2 - 3 } & Reversibility & Any system can be run reversibly \\
\cline { 2 - 3 } & Internal Energy vs. Enthalpy & Internal energy and enthalpy are interchangeable \\
\cline { 2 - 3 } & Steady State vs. Equilibrium & Steady state and equilibrium are interchangeable terms \\
\cline { 2 - 3 } & $\begin{array}{l}\text { Reaction rate vs. Reaction } \\
\text { Equilibrium }\end{array}$ & $\begin{array}{l}\text { Factors which impact how quickly a reaction occurs also impact } \\
\text { how much product is created. }\end{array}$ \\
\hline
\end{tabular}

We then assembled and tested the reliability of multiple choice concept inventories, the Heat and Energy Concept Inventory (HECI) focused on the four heat transfer concepts, and the Concept Inventory for Engineering Thermodynamics (CIET) for the five thermodynamics concepts. 
Finally, for each concept area, we created two inquiry-based activities. These activities incorporate the components of Table 1, with several significant additions. First, all students complete a written prediction and post-activity reflection. This is done to promote accurate recall and help students internalize their experiences in lab. Second, activities were designed with the goal of taking about 15 minutes and being possible using standard lab equipment amended only with items available for less than $\$ 20$ at Walmart.

\section{Methods}

Samples of convenience were used to assess the effectiveness of activities in both heat transfer and thermodynamics. Engineering students at a variety of universities were given either the HECI or the CEIT as a pre- / post- test in both the first and final two weeks of their relevant courses. The characteristics of the concept inventories have been previously described [3; 4] and are sufficiently reliable for use as research instruments. Students in "no activities" classes follow their typical course of instruction without activities, and are therefore used as our "control" treatment. Students in "activities" classes have the eight heat transfer or 10 thermodynamics activities included as part of their coursework. In the thermodynamics data set, there is also a "some activities" grouping, referring to classes where the faculty chose to do the activities for some concept areas but not others. These results are removed from the current post-test analysis.

For the "control", the HECI was administered as a pre-test to 373 undergraduates at 11 institutions. For Heat Transfer, the "activities" group consists of 489 students at the time of the pre-test at 10 different institutions. Demographic description of these students is in Table 3.

TABLE 3: Demographic Information: Heat Transfer

\begin{tabular}{|l|l|l|}
\hline $\begin{array}{l}\text { Demographic } \\
\text { Variable }\end{array}$ & $\begin{array}{l}\text { Control Group } \\
\text { (No Inquiry-based Activities) }\end{array}$ & Activities Group \\
\hline Gender & $26.6 \%$ female, 73.4.1\% male & $23.7 \%$ female, 76.3\% male \\
\hline Race & $\begin{array}{l}80.9 \% \text { White, next largest group, Asian/Pacific } \\
\text { Islander 10\% }\end{array}$ & $\begin{array}{l}73.2 \% \text { White, next largest group, Asian/Pacific } \\
\text { Islander 12.5\% }\end{array}$ \\
\hline Major & $\begin{array}{l}39.5 \% \text { chemical engineering, 47.4 mechanical } \\
\text { engineering, 13.1\% other }\end{array}$ & $\begin{array}{l}49.1 \% \text { chemical engineering, 36.6\% mechanical } \\
\text { engineering, 14.3\% other }\end{array}$ \\
\hline $\begin{array}{l}\text { Year in B.S. } \\
\text { Program }\end{array}$ & Primarily junior (61.3\%) and senior (30.5\%) & $\begin{array}{l}\text { Primarily junior (59.5\%), sophomore (20.03\%), } \\
\text { and senior (18.9\%) }\end{array}$ \\
\hline
\end{tabular}

In thermodynamics, the CIET was given to students in 26 courses. The majority of these students were white (77\%), male $(72.5 \%)$, in their junior $/ 3^{\text {rd }}$ year as engineers (56.7\%), and chemical engineering majors (52.1\%). The second most common major was mechanical engineering (31.8\%). Overall, 920 students took the pre-test, and 720 the post-test. Of these, 271 were in the "control" and 649 were in "activities".

The activities themselves for both thermodynamics and heat transfer are available by contacting the corresponding author. The thermodynamics activities are briefly described in [5]. 


\section{Results and Discussion}

Pre-and post-instruction concept inventory scores are shown in Tables 4 and 5 for heat transfer and thermodynamics respectively. Overall, activities promote significantly better conceptual understanding overall, relative to typical course work.

Table 4. Mean Pre/Post Performance Data by Content Area, With and Without Activities for Heat Transfer

\begin{tabular}{|l|l|l|l|l|}
\hline \multirow{2}{*}{ Content Area } & \multicolumn{2}{l|}{$\begin{array}{l}\text { Mean Score, Control } \\
\text { (no activities) }\end{array}$} & $\begin{array}{l}\text { Mean Score, Test } \\
\text { (w/ activities) }\end{array}$ \\
\cline { 2 - 5 } & $\begin{array}{l}\text { Pre-Test } \\
\mathbf{N = 3 7 3}\end{array}$ & $\begin{array}{l}\text { Post-Test } \\
\mathbf{N}=\mathbf{3 4 4}\end{array}$ & $\begin{array}{l}\text { Pre-Test } \\
\mathbf{N}=\mathbf{4 6 3}\end{array}$ & $\begin{array}{l}\text { Post-Test } \\
\mathbf{N}=\mathbf{3 9 2}\end{array}$ \\
\hline Temperature vs. Energy & $53.6 \%$ & $56.4 \%$ & $52.2 \%$ & $62.7 \%$ \\
\hline Temperature vs. Perceptions of Hot or Cold & & & & \\
& $61.4 \%$ & $70.4 \%$ & $57.6 \%$ & $73.6 \%$ \\
\hline Rate vs. Amount & $36.8 \%$ & $42.6 \%$ & $33.3 \%$ & $63.5 \%$ \\
\hline Thermal Radiation & $44.6 \%$ & $50.8 \%$ & $41.0 \%$ & $63.6 \%$ \\
\hline Overall & $\mathbf{4 9 . 2 \%}$ & $\mathbf{5 4 . 4 \%}$ & $\mathbf{4 6 . 5 \%}$ & $\mathbf{6 6 . 3 \%}$ \\
\hline
\end{tabular}

A one-way analysis of covariance (ANCOVA) showed a significant difference between the heat transfer "activities" group post-test and the "control" group for every sub-test, with the activities group performing better in each one.

TABlE 5. Mean Pre/Post Performance Data by Content Area, With and Without Activities for Thermodynamics

\begin{tabular}{|c|c|c|c|c|}
\hline \multirow[t]{2}{*}{ Content Area } & \multicolumn{2}{|c|}{$\begin{array}{l}\text { Mean Score, Control } \\
\text { (no activities) }\end{array}$} & \multicolumn{2}{|c|}{$\begin{array}{l}\text { Mean Score, Test } \\
\text { (w/ activities) }\end{array}$} \\
\hline & $\begin{array}{l}\text { Pre-Test } \\
N=271\end{array}$ & $\begin{array}{l}\text { Post-Test } \\
N=231\end{array}$ & $\begin{array}{l}\text { Pre-Test } \\
\mathrm{N}=649\end{array}$ & $\begin{array}{l}\text { Post-Test } \\
\mathrm{N}=205\end{array}$ \\
\hline Entropy / second law & 50.0 & $63.9 \%$ & $49.6 \%$ & $68.0 \%$ \\
\hline Reversibility & $51.6 \%$ & $57.4 \%$ & $51.7 \%$ & $68.3 \%$ \\
\hline Internal Energy vs. Enthalpy & $26.5 \%$ & $38.5 \% *$ & $29.5 \%$ & $55.5 \%$ \\
\hline Steady State vs. Equilibrium & $49.8 \%$ & $60.5 \%$ & $48.4 \%$ & $76.2 \%$ \\
\hline Rate of reaction vs. Reaction Equilibrium & $36.4 \%$ & $39.8 \%$ & $41.0 \%$ & $54.4 \%$ \\
\hline Overall & $44.3 \%$ & $53.9 \%$ & $47.5 \%$ & $66.1 \%$ \\
\hline
\end{tabular}

For both control and "activities", students perform better after instruction. However, students in the "activities" group outperform their control group peers significantly for four of the five areas (not Entropy). While not as large as the gains for heat transfer, overall students performing thermodynamics activities outperform their "control" peers in conceptual understanding.

Overall, activities provide a significant improvement for conceptual understanding. While it might seem that improvements are less spectacular than they might be - students typically improve about 10 percentage points relative to control - the results are important for two reasons. First, these post-tests are from the conclusion of the semester, up to two months after students completed some of the activities. Students' written feedback immediately after activities, at the time when interventions are typically assessed, demonstrates higher levels of conceptual understanding. We report the long-term results as they are the most important, demonstrating that while not every students' misconceptions have 
been repaired, most students have experienced long-term misconception repair. Second, these results follow from just two $\sim 15$ minute activities in each concept area. That is, relative to the entire time students devote on this course, a relatively tiny additional investment creates significant change in conceptual understanding.

For future work, we plan to continue analysis of these data to better understand how students' understanding changes over time and transfers to novel situations. We also plan to isolate the impact of particular activities on the post-test scores. Finally, we are revising and re-envisioning our heat transfer activities to make them more "adoptable" by faculty, in an effort to spread improved conceptual understanding more widely.

\section{Acknowledgements}

We gratefully acknowledge the support of the National Science Foundation, CCLI \#0442234 and 0717536, as well as TUES 1225031.

This work was also helped by Ruth Streveler, John Pershetti, Jeff Detrich, Emily Eherenberger, Jeff Stein, and Daniel Prudente.

\section{Bibliography}

1. Bransford, J., A. Brown, and R. Cocking. How People Learn: Brain, Mind, Experience and School. Washington, D.C.: Commission on Behavioral and Social Science and Education, National Research Council, 2000.

2. Laws, P., Sokoloff, D., and Thornton, R. "Promoting active learning using the results of physics education research." UniServe Science News 13 (1999):

3. Prince, Michael, Vigeant, Margot, and Nottis, Katharyn. "Assessing the prevalence and persistence of engineering students' misconceptions in heat transfer." Journal of Engineering Education 101, no. 3 (2012): 412-38.

4. Vigeant, M., Michael Prince, and Katharyn Nottis. 'Engineering Undergraduates' Conceptual Understanding of Thermodynamics: Assessment and Change After Normal Instruction.” Paper presented at the Hawaii International Conference on Education, Honolulu, HI, 2011.

5. Vigeant, M., M. Prince, and K. Nottis. "Making Their Brains Hurt: Quick and Effective Activities for Thermodynamics." Paper presented at the Proceedings of the American Association for Engineering Education, San Antonio, TX, 2012. 